\title{
Implementation of a Psycho-Oncology Program according to international recommendations applied in a Brazilian Public Service
}

Cristiane Decat Bergerot. Universidade Federal de São Paulo

Carolina Gaue Zayat. Universidade Federal de São Paulo

Isadora Miranda de Azevedo. Universidade Federal de São Paulo

Getulio Yuzo Okuma. Universidade Federal de São Paulo

Renata Nunes Pedras. Universidade Federal de São Paulo

Maria Fernanda Marcusso Manhães. Universidade Federal de São Paulo

Edvane Birelo Lopes De Domenico. Universidade Federal de São Paulo

\begin{abstract}
The development of international guidelines for distress assessment gave greater visibility to the importance of psychosocial issues within Oncology services. This study sought to identify the instruments used in Brazil, to describe the procedures for implementing this program and to present the preliminary results of a public hospital. In Brazil these recommendations are little broadcast. However, the feasibility and benefits of this new model of care were proved. There was a substantial increased number of patients seen, suggesting agility for distress identification. This program organized and optimized the cancer care, facilitated interprofessional communication, and ensured the identification of patients' needs.
\end{abstract}

Keywords: psycho-oncology; cancer care; distress; psychosocial assessment.

\section{Resumo}

Implementação de Programa de Psico-Oncologia segundo recomendações internacionais aplicadas em Serviço Público Brasileiro. A elaboração de protocolos internacionais para avaliação do distress deu maior visibilidade para a inserção do domínio psicossocial nos serviços de Oncologia. Esse estudo procurou identificar os instrumentos utilizados no Brasil, descrever os procedimentos para implementação dessas diretrizes e apresentar os resultados preliminares de um hospital público. No Brasil, essas recomendações se encontram pouco difundidas. Entretanto, comprovou-se a viabilidade e benefícios desse novo modelo de atendimento. Houve um aumento substancial no número de pacientes atendidos, sugerindo agilidade para identificação do distress. Esse programa organizou e otimizou a assistência, facilitou a comunicação interprofissional e garantiu a identificação das necessidades dos pacientes.

Palavras-chave: psico-oncologia; rotina; distress; avaliação psicossocial.

\section{Resumen}

Aplicación de Rutina de Psico-Oncología segundo las recomendaciones internacionales aplicadas en el Servicio Público Brasileño. El desarrollo de protocolos internacionales para la evaluación de distress dio mayor visibilidad a la importancia del dominio psicosocial en servicios de Oncología. Este estudio buscó identificar los instrumentos utilizados en Brasil, describiendo los procedimentos para la aplicación de estas directrices y presentar los resultados preliminares de un servicio publico. En Brasil, estas recomendaciones se transmiten aún poco. Sin embargo, se ha comprobado la viabilidad y beneficios de este nuevo modelo de atención. Hubo un aumento sustancial en el número de pacientes vistos, sugiriendo agilidad para la identificación de distress. Este programa organizó y optimizó la assistencia, facilitó la comunicación interprofesional y aseguró la identificación de las necessidades de los pacientes.

Palabras clave: psico-oncología; rutina; distress; evaluación psicossocial. 
In recent years, there has been a significant increase in the recognition of the importance of Psycho-Oncology care. Much of this recognition arose in response to the publication of a psychosocial screening program, as a standard of care of patients with cancer (Jacobsen, Holland, \& Steensma, 2012). This initiative was based on the guideline "Distress Management" published by the National Comprehensive Cancer Network (NCCN), in which the term distress is proposed to designate the biopsychosocial impact of cancer (Holland et al., 2013). Specifically, the definition of this term means "a multifactorial unpleasant experience of a psychological, social, spiritual, and/or physical nature that may interfere with the ability to cope effectively with cancer, its physical symptoms, and its treatment" (Holland et al., 2013).

This term was chosen to overcome the stigma commonly associated with cancer, in favor of an expression that is better accepted and that make the language more clear and simple (Holland et al., 2013). However, this is not a new nosographic category to be included in the Diagnostic and Statistical Manual of Mental Disorders (Carlson, Waller, \& Mitchell, 2012). The clinical value of distress is based on establishing some criteria for diagnostic screening in multiple domains (Bultz, Loscalzo, \& Clark, 2012). This includes mood disorders or anxiety and a wide range of signs and symptoms, such as fatigue, insomnia, nutritional and financial problems (Gregório et al., 2013).

In the United States, various organizations and institutions endorsed the use of the recommendations proposed by NCCN. This action gave greater visibility to the importance of the psychosocial domain in cancer care (Holland et al., 2013; Jacobson et al., 2009). Other countries also joined and included similar recommendations in their guidelines: Australia (National Health \& Medical Research Council, 2003), Canada (Canadian Partnership Against Cancer, 2013) and United Kingdom (National Institute for Clinical Excellence, 2004).

These aspects have gained prominence exponentially, demonstrating great potential to integrate within various health systems. In the Oncology field, the distress screening presents itself as a symbol of quality of care, that ensures a patient-centered care and that helps the health care team to meet the real needs of their patients (Bultz et al., 2012). The proposal is that the service should not only be based on the type of cancer or the severity of the disease, but on the needs reported by each patient (Loscalzo, Clark, Pal, \& Pirl, 2013).
The Brazilian Society of Psycho-Oncology (Sociedade Brasileira de Psico-Oncologia, SBPO) joined and endorsed the standard proposed by the International Psycho-Oncology Society (IPOS) (2013). Some studies have demonstrated the viability of the inclusion of this screening in Brazil (Albuquerque \& Pimenta, 2014; Bergerot et al., 2016; Lera et al., 2011). However, there is little information about the adherence of Brazilian professionals to these standards and no study on the implemenation of theses standards in a public service. In order to address this lack of information, the present study was carried out in three phases that aimed to: (1) characterize the use of screening measures for psychologists from different Oncology service, (2) describe the program implemented and developed on the basis of existing international guidelines, and (3) present the preliminary results from the this implementation.

\section{Methods}

\section{First Phase of the Study: Characterization of the Psycho-Oncology services in Brazil}

A descriptive study was conducted through an online search tool, surveymonkey, in the period between June and August of 2016. Psychologists from hospitals and cancer centers located in different Brazilian cities were invited to answer a structured questionnaire. This project was submitted and approved by the ethics and research committee (Comitê de Ética e Pesquisa, CEP), number 021199/2016, of the Federal University of Sao Paulo (Universidade Federal de São Paulo, UNIFESP). After completion of the study, a descriptive analysis of the data was completed, and the correlation between the total of patients seen and the use of a psychosocial screening instrument was assessed.

\section{Second Phase of the Study: Description of a Psy- cho-Oncology Program}

The UNIFESP oncology service, located in Sao Paulo, is designated as a Center of High Complexity in Oncology (Centro de Alta Complexidade em Oncologia, CACON). In clinical Oncology, different clinics were structured in order to treat patients diagnosed with different types of cancer. Because it is an academic hospital, medical residents and other health specialties (psychology, nursing, pharmacy, nutrition, physiotherapy, social work and dentistry) make up the teams that assist patients from an integrated multidisciplinary perspective. 
In the run-up to the implementation of the new program, the Psycho-Oncology service was structured to offer psychotherapy on demand; patients were referred by the multidisciplinary team, by the physician or by patient request. Considering the specific needs of cancer patients, it was proposed that in May of 2015, a program that optimizes the existing service, identify risk factors and broadens the access of patients and family members to the psychology service, be implemented. To this end, the existing international standards were used as a foundation.

After the program was developed, the proposal was presented and discussed with the Oncology staffs. With the approval of the team, the process was gradually implemented. Patients were assessed before their appointments with validated instruments for this population (Distress Thermometer, Hospital Anxiety and Depression Scale, and Functional Assessment of Cancer Therapy-General). The results were classified in risk criteria and then discussed with the team in order to establish treatment according to standards described in internationals guidelines (Canadian Partnership Against Cancer, 2013; Holland et al., 2013; National Health \& Medical Research Council, 2003; National Institute for Clinical Excellence, 2004). After 3 months of implementation, the results were presented to the team and the program was discussed once more.

\section{Third phase of the Study: Evaluation of the Main Results}

\section{Participants}

The sample included 736 patients, aged 18 or older, diagnosed with cancer, undergoing treatment or clinical follow-up. These patients were contacted and assessed by the psychologist residents and the tutor of the Multidisciplinary Oncology Residency Program, over the period of June, 2015 to August, 2016, in the Oncology outpatient service of the UNIFESP. This study was approved by the CEP of the UNIFESP, number 0764/2015. All participants signed the consent form before data collection.

\section{Instruments}

Patients were assessed across distress, anxiety, depression, and quality of life. Sociodemographic and clinical data were identified in the electronic medical records of each patient.

Distress was assessed using the Distress Thermometer (DT), an instrument developed and proposed by the NCCN (Holland et al., 2013), translated and validated to the Portuguese language by Decat, Laros and Araujo (2009). Comprises an 11-point scale (0-without distress to 10-extreme distress) that evaluate the level of distress, and a Problem List with 35 items subdivided into practical, family, emotional, and physical domains. A score greater than or equal to four indicates a moderate to severe distress (Decat et al., 2009).

The Hospital Anxiety and Depression Scale (HADS) version, translated and validated for the Portuguese language by Botega et al. (1995), was used to assess symptoms of anxiety and depression. It is composed of two subscales, with seven items each, to assess symptoms of anxiety and depression. The score of each subscale ranges from 0 to 21 ; with a score greater than or equal to eight being indicative of moderate to severe symptoms of anxiety and a score nine or more of depression (Botega et al., 1995).

Quality of life was measured by the Functional Assessment of Cancer Therapy-General (FACT-G), an instrument developed for adult cancer patients, translated and validated to the Portuguese language by Arnold et al. (2000). Containing 27 items that assess the physical, family/social, emotional and functional wellbeing, on a Likert scale from 0 to 4 . Scores range from 0 to 108 , with a higher score indicative of a better quality of life (Arnold et al., 2000).

\section{Data Analysis}

In order to characterize the sample, a descriptive analysis of the sociodemographic and clinical data was done. The prevalence of distress, anxiety and depression was estimated, being subsequently analyzed the mean and standard deviation of the quality of life scores. The correlation between distress, anxiety, depression and quality of life scales was explored. Finally, a logistic regression (stepwise method) was used to assess the predictive value of moderate to severe distress and symptoms of anxiety, depression, and quality of life. All analyses were conducted using the software SPSS 22.0.

\section{Results}

\section{First Phase of the Study: Characterization of the Psycho-Oncology Services in Brazil}

A total of 88 psychologists took part in this phase of the study; $56.8 \%$ reported knowing and following the IPOS recommendations. These psychologists worked in private 
(48.9\%) or public (51.1\%) institutions, located in 35 cities (Most frequent: $22.7 \%$ Sao Paulo, 8.0\% Belo Horizonte, 4.5\% Porto Alegre, $4.5 \%$ Brasilia and $4.5 \%$ Recife), belonging to 19 States (Most frequent: $38.6 \%$ Sao Paulo, 8.0\% Minas Gerais and 8.0\% Rio Grande do Sul), and distributed in five regions of Brazil (12.5\% South, $46.6 \%$ South-East, 19.4\% Midwest, $4.5 \%$ North and $17.0 \%$ Northeast).

The psychologists reported working alone or in teams of up to 40 individuals ( $M=3.7 ; S D=6.2$ ); they saw an average of 113 patients per month (Min = 7 Max = 1,450; $S D=224.4$ ). Just $34.1 \%$ used an instrument to assess psychosocial aspects. There was a significant correlation between the number of patients seen by the psychologist, and the use of psychosocial screening tool $(p=0.04)$, suggesting that in those institutions where a greater number of patients were seen, a psychosocial screening tool was more likely to be utilized.

Few (19.3\%) opted to use multiple measures that, in general, evaluate the triad: distress, anxiety/depression and quality of life. The most widely used tools were: HADS (19.3\%), DT (13.6\%), FACT (5.7\%), World Health Organization Quality of Life (WHOQOL; 4.5\%), ShortForm 36 (2.3\%), European Organization for Research and Treatment of Cancer (EORTC; 2.3\%) and Beck Scales (2.3\%). In general, patients were screened every hospitalization or every visit (19.3\%), when there was a change in their disease status (18.2\%), and when the health team (15.9\%) and/or the patient requested (14.8\%).

\section{Second Phase of the Study: Description of a Psycho-Oncology Program}

In the calculation of the representativeness of the service in the previous phase, before the implementation of the screening program, it was found that only $3.5 \%$ of the total number of patients were seen by the
Psycho-Oncology service. After the implementation of the program, this percentage gradually increased from 25.8\% in June, 2015 to $70.5 \%$ in August, 2016.

After the translation and adaptation of the international standard into an effective strategy, consistent with the institution's culture, the program was subdivided in six actions (Figure 1). Initially, patients were assessed in clinics using the DT, HADS, and FACT-G. The patient's needs were classified by risk criteria (Figure 1 and Figure 2). All patients' needs were then discussed among the Psychology team. At the end of the clinic, a synthesis of all patients' needs identified were presented and discussed with the medical staff and multidisciplinary team (Figure 1).

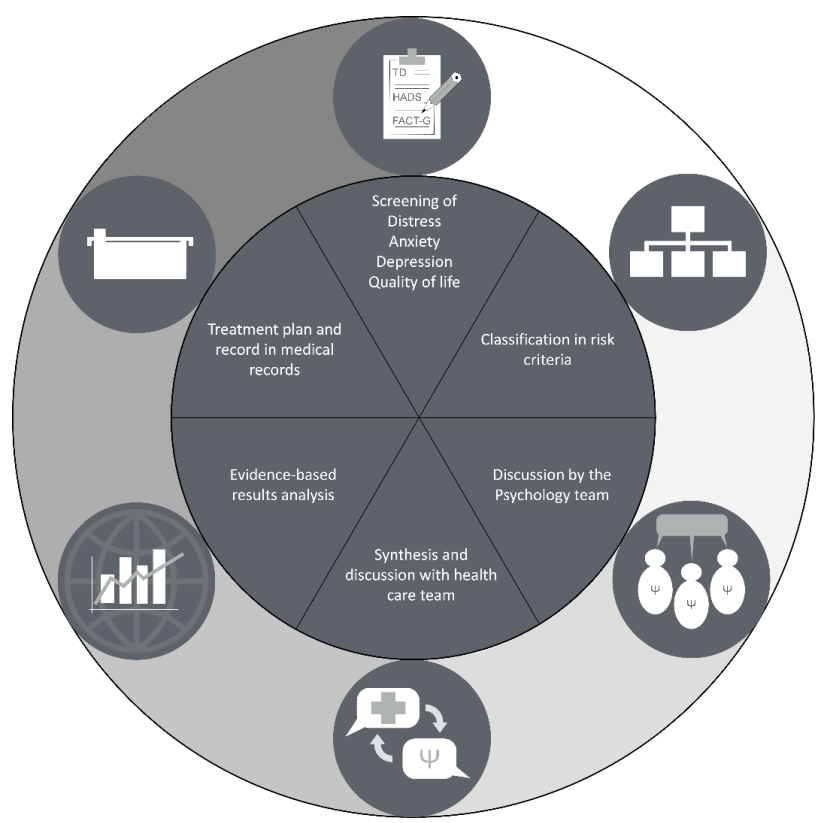

Figure 1. Flow Chart of the UNIFESP Psycho-Oncology Program.

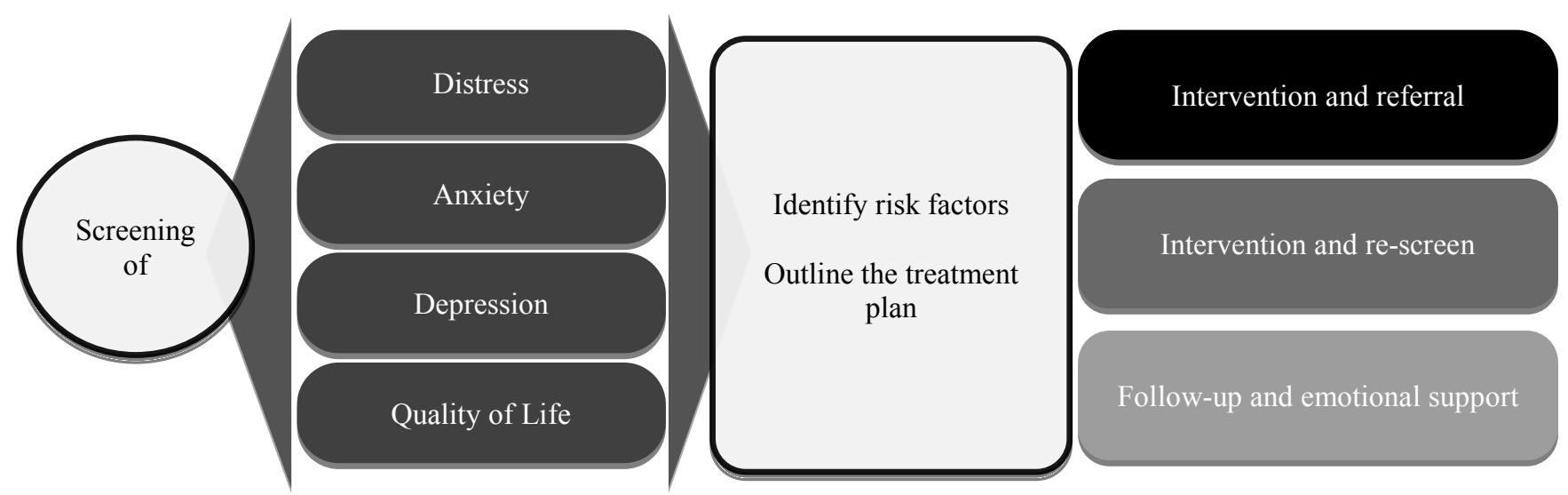

Figure 2. Synthesis of the Screening and Risk Classification. 
Subsequently, the data was analyzed according to the parameters and available evidence described in the literature, to gain greater understanding of clinical outcomes and to propose actions and programs that can promote the reduction or even the prevention of most frequently reported demands. All information was documented in the medical records of each patients (Figure 1). The reassessment was made quarterly, using all instruments mentioned above. In cases in which the patients was considered at medium or high risk, the demands identified were followed closely by the psychologist, in order to define whether the treatment and intervention proposed were effective or if there was a need for new therapeutic planning (Figure 2). In cases where there was a transition or disease status change, the critical steps of greater fragility and emotional vulnerability, a new assessment was proposed.

Among the qualitative indicators perceived on the verbal reports of the team, which were recorded along the implementation phase of this program, it has been noted: (1) a greater integration between the psychology residents and the multidisciplinary team and physician, (2) a greater recognition and understanding about the importance of the Psycho-Oncology service by other professionals, and (3) a greater satisfaction among psychology residents, which currently refer an improvement on their knowledge in this field. From the patient point of view, it has been observed: (1) a greater accessibility to Psycho-Oncology service, (2) an easier way to recognize and report the difficulties experienced, (3) more opportunities to treat preemptively or proactively the demands reported, and (4) an improvement in physician-patient-team communication.

\section{Third Phase of the Study: Evaluation of the Main Results}

Most of the population seen and evaluated by Psycho-Oncology team $(N=736)$ was female $(54.3 \%)$, between 18 and 96 years of age $(M=54.9 ; S D=15.7)$, being married (54.9\%), had at least elementary school (58.7\%) and referred a monthly income of up to one minimum wage ( $\$$ \$ 788.00; 66.0\%). Gastrointestinal (22.7\%), breast (16.1\%) and central nervous system (15.0\%) cancers were the most common, with $66.4 \%$ being diagnosed with advanced disease stage (III-IV). When assessed, $71.6 \%$ were receiving treatment.

A high prevalence $(46.6 \%)$ of moderate to severe distress has been reported by patients. Emotional (70.1\%) and physical (91.2\%) problems were the most frequent reported; highlighting financial (36.4\%), worry
(56.7\%), nervousness $(42.4 \%)$, sadness $(36.7 \%)$, pain (46.7\%), fatigue (41.2\%), memory and/or concentration (36.0\%). About $23.0 \%$ of the patients reported moderate to severe symptoms of anxiety and $13.0 \%$ of depression. The average quality of life was $82.3(S D=16.8)$, with better scores on the physical $(M=22.4 ; S D=5.7)$, social/family ( $M=20.8 ; S D=4.9)$, emotional $(M=19.5$; $S D=4.6)$ and functional $(M=19.8 ; S D=6.4)$ well-being.

A significant correlation was found between distress, anxiety and depression $(r=0.78 ; p<0.001)$ and conversely between distress and quality of life $(r=0.83$; $p<0.001)$. In logistic regression, moderate to severe distress was a predictor of symptoms of anxiety and depression $\left[F(2,735)=5.56, p=0.000 ; R^{2}=0.37\right]$ and low scores of quality of life $\left[F(5,735)=5.05, p=0.000 ; R^{2}=0.43\right]$.

\section{Discussion}

Psychologists from different Oncology services in Brazil choose standard instruments that are recommended and commonly used internationally in patient care (HADS and DT) (Bergerot et al., 2016; Holland et al., 2013; Mitchell, 2010). Despite the scientific evidence regarding the benefits of psychosocial screening, it was found that the IPOS recommendation has been only partially disseminated among psychologists in Brazil. However, these standards in Brazilian oncology service have been proved to be feasible and actionable, even in the complex context of a large general public hospital. The program proposed substantially increased the representativeness of the Psycho-Oncology service, suggesting agility of the new care model and a broadening of access of psychosocial support to cancer patients. Furthermore, the high prevalence of distress, anxiety and depression in this population reinforces the relevance of a screening program to identify these biopsychosocial needs.

In the current institution, relatively few difficulties were noted and little resistance to implementation of international care standards. The changes incorporated were well accepted by the health care team and by patients. This program has reorganized the service, facilitated interprofessional communication and optimized cancer care. It was noted that the work provided by the psychologists became more active and recognized by the health care team and by patients. The uniqueness of the patient was ensured, even with the increased number of patients assisted and when screening was performed by different psychologists. International standards have ensured that relevant 
information was prioritized and could be structured after each patient consultation.

The prevalence of distress was high compared to developed countries (Zabora, BrintzenhofeSzoc, Curbow, Hooker, \& Piantadosi, 2001). However, it is possible to contextualize this result based on the difficulties and challenges faced in a developing country, the characteristics of the population and the expected impact of the diagnosis and treatment. The prevalence of symptoms of anxiety and depression were close to those described in the national and international literature (Bergerot, 2016; Grassi et al., 2004) and the quality of life scores were equivalent to the average reported by the American population with cancer (Brucker, Yost, Cashy, Webster, \& Cella, 2005). These results confirm the relevance of the screening program of patients' needs related to coping with cancer, suggesting a potential intervention model.

Further, these findings promote the development of strategies that favor equity of cancer care and the offering of interventions in a timely manner, avoiding a possible worsening of symptoms. Future studies should be developed in order to demonstrate the benefit of these interventions. In addition, it was identified that some demands need to be better addressed, such as, for example, those reported by family caregivers. Furthermore, the comparative analysis aided in the identification of new psychological risk factors; for example, financial problems, has been considered one factor that can aggravate symptoms of distress, anxiety, depression and quality of life (Meeker et al., 2016).

The fact that distress can predict symptoms of anxiety and depression, and a worse quality of life, is consistent with the relevant international standards. In addition, it is important to consider the level of scientific evidence (Grade II recommendation, based on systematic review and randomized and controlled studies) of the assessment of distress on the screening of depression (Li et al., 2016), and the significant benefit of psychological intervention in reducing these symptoms (Kissane et al., 2007). However, the limitations of the present study should be considered, such as: the fact that the international standards was implemented in one institution, not allowing for the generalization of these results, in addition the absence of a control group for validation of the benefits identified and the fact that some benefits observed were not measured, for example, the benefits perceived by the health care team.
Currently, it is not possible to implement a Psycho-Oncology program without considering the available evidence and the standards proposed in consensus by different experts. It is also hard to offer a quality service without regard to the instruments and standards recommended for the assessment and treatment of the psychosocial needs of cancer patients. The current study demonstrates that the instruments used (DT, HADS and FACT-G) were adequate for the identification of patients' needs throughout the continuum of cancer. In addition, the development of this screening program, including risk classification and the therapeutic plan, achieved the goal of better meeting the psychosocial needs of each cancer patients.

\section{References}

Albuquerque, K. A., \& Pimenta, C. A. (2014). Distress do paciente oncológico: prevalência e fatores associados na opinião de familiares. Revista Brasileira de Enfermagem, 67(5), 744-751. doi: 10.1590/0034-7167.2014670511

Arnold, B. J., Eremenco, E., Chang, C. H., Odom, L., Ribaudo, J., \& Cella, D. (2000). Development of a single Portuguese language version of the functional assessment of cancer therapy general (FACT-G) scale. Quality of Life Research, 9(3), 316. doi: 10.1023/A:1017291624003

Bergerot, C. D., Philip, E. J., Schuler, T. A., Clark, K. L, Loscalzo, M., Buso, M. M., ... Araujo, T. C. C. F. (2016). Development and implementation of a comprehensive psychosocial screening program in a Brazilian cancer center. Psycho-Oncology, 25(11), 1343-1349. doi: 10.1002/pon.4275

Botega, N. J., Bio, M. R., Zomignani, M. A., Garcia Jr., C., \& Pereira, W. A. B. (1995). Transtornos de humor em enfermaria de clínica médica e validação de escala de medida (HAD) de ansiedade e depressão. Revista de Saúde Pública, 29(5), 355-363. doi: 10.1590/ S0034-89101995000500004

Brucker, P. S., Yost, K., Cashy, J., Webster, K., \& Cella, D. (2005). General population and cancer patient norms for the functional assessment of cancer therapy-general (FACT-G). Evaluation \& The Health Professions, 28(2), 192-211. doi: 10.1177/0163278705275341

Bultz, B. D., Loscalzo, M. J., \& Clark, K. L. (2012). Screening for distress, the 6th vital sign, as the connective tissue of health care systems: A roadmap to integrated interdisciplinary person-centered care. In L. Grassi \& M. Riba (Eds.), Clinical psycho-oncology: An international perspective (pp. 83-96). Oxford, UK: John Wiley \& Sons Ltda.

Canadian Partnership Against Cancer. (2013). Screening for distress the 6th vital sign: A guide to implementation best practices in person-centered care. Toronto, Canada: Author.

Carlson, L. E., Waller, A., \& Mitchell, A. J. (2012). Screening for distress and unmet needs in patients with cancer: Review and recommendations. Journal of Clinical Oncology, 30(11), 1160-1177. doi:10.1200/ JCO.2011.39.5509

Decat, C. S., Laros, J. A., \& Araujo, T. C. C. F. (2009). Termômetro de distress: validação de um instrumento breve para avaliação diagnóstica de pacientes oncológicos. PsicoUSF, 14(3), 253-260. doi: 10.1590/S1413-82712009000300002 
Implementation of a Psycho-Oncology Program according to international recommendations applied in a Brazilian Public Service

Grassi, L., Travado, L., Gil, F., Sabato, S., Rossi, E., \& The SEPOS Group. (2004). Psychosocial morbidity and its correlates in cancer patients of the Mediterranean area: Findings from the Southern European Psycho-Oncology Study (SEPOS). Journal of Affective Disorders, 83, 243-248. doi: 10.1016/j.jad.2004.07.004

Gregório, S. W-D., Porensky, E., Minotti, M., Brown, S., Snapp, J., Taylor, R. M., ... Andersen, B. L. (2013). The James supportive care screening: Integrating science and practice to meet the NCCN guidelines for distress management at a comprehensive cancer center. Psycho-Oncology, 22(9), 2001-2008. doi: 10.1002/pon.3256

Holland, J. C., Andersen, B., Breitbart, W. S., Buchmann, L. O, Compas, B., Deshields, T. L, ...Freedman-Cass, D. A. (2013). Distress management. Journal of the National Comprehensive Cancer Network, 11(2), 190-209. doi: 10.6004/jnccn.2013.0027

International Psycho-Oncology Society (2013). Standards of care news: Endorse the statement. Retrieved from http://ipos-society.org/about/ news/standards_news.aspx"

Jacobsen, P. B., Holland, J. C., \& Steensma, D. P. (2012). Caring for the whole patient: the science of psychosocial care. Journal of Clinical Oncology, 30(12), 1-3. doi: 10.1200/JCO.2011.41.4078

Jacobson, J. O., Polovich, M., McNiff, K. K., LeFebvre, K. B., Cummings, C., Galioto, M., ... McCorkle, M. R. (2009). American Society of Clinical Oncology/Oncology Nursing Society chemotherapy administration safety standards. Journal of Clinical Oncology, 27(22), 5469-5475. doi: 10.1200/JCO.2009.25.1264

Kissane, D. W., Grabsch, B., Clarke, D. M., Smith, G. C., Love A. W., Bloch, S., ... Li, Y. (2007). Supportive-expressive group therapy for women with metastatic breast cancer: Survival and psychosocial outcome from a randomized controlled trial. Psycho-Oncology, 16(4), 277-286. doi: 10.1002/pon.1185

Lera, A. T., Miranda, M. C., Trevizan, L. L. B., Antonangelo, D. V., Zanellato, R. M., Tateyanam L. T. C., ... Giglio, A. (2011). Aplicação do instrumento termômetro de estresse em pacientes idosos com câncer: estudo piloto. Revista Brasileira de Clinica Médica, 9(2), 112-116. Retrieved from http://www.sbcm.org.br/revistas/RBCM/ RBCM-2011-02.pdf

Li, M., Kennedy, E. B., Byrne, N., Gérin-Lajoie, C., Katz, M. R., Keshavarz, H., ... Green, E. (2016). Management of depression in patients with cancer: a clinical practice guideline. Journal of Oncology Practice, 12(8), 747-756. doi: 10.1200/JOP.2016.011072

Loscalzo, M., Clark, K., Pal, S., \& Pirl, W. F. (2013). Role of biopsychosocial screening in cancer. Cancer Journal, 19(5), 414-420. doi: 10.1097/PPO.0b013e3182a5bce2

Meeker, C. R., Geynisman, D. M., Egleston B. L., Hall, M. J., Mechanic, K. Y., Bilusic, M., ... Wong, Y. N. (2016). Relationships among financial distress, emotional distress, and overall distress in insured patients with cancer. Journal of Oncology Practice, 12(7): e755-e764. doi: 10.1200/JOP.2016.011049

Mitchell, A. J. (2010). Short screening tools for cancer-related distress: A review and diagnostic validity meta-analysis. Journal of National Comprehensive Cancer Network, 8(4), 487-494. doi: 10.6004/ jnccn.2010.0035

National Health \& Medical Research Council (2003). Clinical practice guideline for the psychosocial care of adults with cancer. Retrieved from http://www.nhmrc.gov.au/_files_nhmrc/publications/attachments/cp90.pdf.

National Institute for Clinical Excellence. (2004). Improving supportive and palliative care for adults with cancer. The manual. London: Author.

Zabora, J., BrintzenhofeSzoc, K., Curbow, B., Hooker, C., \& Piantadosi, S. (2001). The prevalence of psychological distress by cancer site. Psycho-Oncology, 10(1), 19-28. doi: 10.1002/1099-1611(200101/02)10:1\%3C19::AIDPON501\%3E3.0.CO;2-6 
Cristiane Decat Bergerot, Doutora em Psicologia da Saúde pela Universidade de Brasília (UnB), Pós-Doutorado pela Universidade Feredal de São Paulo (UNIFESP) e bolsista de Pós-doutorado pelo City of Hope Comprehensive Cancer Center, é tutora/preceptora em Psico-Oncologia da Residência Multiprofissional em Oncologia

da Universidade Federal de São Paulo. Endereço para correspondência: Rua Napoleão de Barros, 754, Vila Clementino, Cep: 04024-002, São Paulo, SP. E-mail: crisbergerot@gmail.com

Carolina Gaue Zayat, Especialista em Psicologia da Saúde pelo Programa de Residência, multiprofissional em Oncologia

(Área: Psico-Oncologia), é residente do Programa de Residência Multiprofissional em Oncologia (Psico-Oncologia) na Universidade Federal de São Paulo (UNIFESP). E-mail: zayat.carolina@gmail.com

Isadora Miranda de Azevedo, Especialista em Psicologia da Saúde pelo Programa de, residência multiprofissional em Oncologia (Área: PsicoOncologia), é residente do Programa de Residência Multiprofissional em Oncologia (Psico-Oncologia) na Universidade Federal de São Paulo (UNIFESP). E-mail: azevedoisadora22@gmail.com

Getulio Yuzo Okuma, Especialista em Psicologia da Saúde pelo Programa de Residência, multiprofissional em Oncologia

(Área: Psico-Oncologia), é residente do Programa de, residência multiprofissional em Oncologia (Psico-Oncologia) pela Universidade

Federal de São Paulo (UNIFESP). E-mail: geyuzo@gmail.com

Renata Nunes Pedras, Especialista em Psicologia Hospitalar (Área: Reabilitação Física) pela Universidade de São Paulo (USP), é residente do Programa de Residência Multiprofissional em Oncologia (Psico-Oncologia) na Universidade Federal de São Paulo (UNIFESP).

E-mail: renatanunespedras@gmail.com

Maria Fernanda Marcusso Manhães, graduada em Psicologia pela Universidade Federal de Santa Catarina (UFSC), é residente do Programa de Residência Multiprofissional em Oncologia (Psico-Oncologia) na Universidade Federal de São Paulo (UNIFESP). E-mail: manhaes.mfernanda@gmail.com

Edvane Birelo Lopes De Domenico, Doutora em Enfermagem pela Universidade de São Paulo (USP), é Professora Adjunta da Escola

Paulista de Enfermagem (EPE), Departamento de Enfermagem Clínica e Cirúrgica, Universidade Federal de São Paulo (UNIFESP) e Tutora/Preceptora em Enfermagem da Residência Multiprofissional em Oncologia na UNIFESP. E-mail: domenico.edvane@unifesp.br 